\title{
Mixed cultures in milk of a proteinase-positive and a proteinase-negative variant of Lactococcus lactis subsp lactis: influence of initial percentage of proteinase-positive cells on the growth parameters of each strain and on the rate of acidification
}

\author{
V Juillard, J Richard \\ Station de Recherches laitières, INRA, 78352 Jouy-en-Josas, France
}

(Received 14 April 1993; accepted 16 August 1993)

\begin{abstract}
Summary - The interactive growth of a proteinase-positive (Prt+) and a proteinase-negative variant (Prt) of a strain of Lactococcus lactis subsp lactis has been studied in milk. Simplified models have been used to describe the changes in population of each type of cells and in the acidification rate of the milk. A clear interaction was observed between the 2 types of cells as soon as the non-protein fraction was exhausted. The population level of the mixed culture (ie $\mathrm{Prt}^{+}+\mathrm{Prt}$ ) then corresponded exactly to the population level at which the $\mathrm{Prt}^{+}$starts its second exponential growth phase or the Prt stops growing exponentially, when these strains are grown separately. In the mixed culture, growth of the Prt variant was stimulated, which resulted in the appearance of a second exponential growth phase for this variant and an increase in its final number of cells, when compared with that of the pure culture. On the other hand, the parental strain in the mixed culture showed a lower growth rate during the second exponential growth phase and a lower final population level than the same strain in the pure culture. The extent of these effects depended upon the initial percentage of the $\mathrm{Prt}^{+}$strain in the mixture: the higher this percentage, the stronger the stimulation of the growth of the Prt strain. On the other hand, the lower this percentage, the stronger the inhibition of the growth of the $\mathrm{Prt}^{+}$strain. As a result of this interaction, milk acidification rates were significantly lower under the critical limit of $20 \% \mathrm{Prt}^{+}$cells in the inoculum. Consequently, the time taken to coagulate milk was markedly longer.
\end{abstract}

Lactococcus lactis / mixed-strain milk culture / proteinase activity / interactive growth

Résumé - Cultures mixtes dans le lait d'une souche protéase-positive et d'un variant protéase-négatif de Lactococcus lactis subsp lactis : influence du pourcentage initial de cellules protéase-positives sur les paramètres de croissance cellulaire des 2 souches et sur la vitesse d'acidification du lait. L'interaction entre une souche protéolytique (Prt') de Lactococcus lactis subsp lactis et un variant non protéolytique (Prt) au cours de leur culture dans le lait a été étudiée à l'aide d'un modèle simplifié de croissance cellulaire et d'acidification du lait. Une interaction 
nette intervient aussitôt que la fraction non protéique du lait a été épuisée pour la croissance de ces 2 souches. Le niveau de population totale de la culture mixte atteint à ce moment correspond à celui auquel la souche Prt+ entre dans sa deuxième phase de croissance exponentielle, et à celui auquel la souche Prt sort de son unique phase exponentielle de croissance, lorsque ces 2 souches sont cultivées isolément. L'association des 2 souches entraine une stimulation de la souche Prt alors que la souche Prt+ est en partie inhibée. Cela correspond, pour la première, à l'apparition d'une seconde phase exponentielle de croissance et à un niveau final nettement supérieur à celui atteint par cette souche en culture pure. Pour la souche Prt', l'inhibition se traduit par une réduction du taux de croissance au cours de la deuxième phase et un niveau final plus faible que pour la culture pure. L'intensitè de l'interaction dépend du pourcentage initial de la culture en cellules $\mathrm{Prt}^{+}$: plus ce pourcentage est élevé, plus la stimulation de la souche Prt-est forte. Inversement, plus ce pourcentage initial est faible, plus l'inhibition de la souche $P r^{+}$parait nette. Il en résulte une vitesse d'acidification du lait très ralentie, en particulier au-dessous d'un seuil initial de $20 \%$ de cellules Prt'.

\section{Lactococcus lactis / activité protéolytique / culture mixte / interaction}

\section{INTRODUCTION}

It is well known that the initial growth of lactococci in milk is closely determined by the non-protein nitrogen (NPN) content of this medium. As long as NPN is available, both proteinase-positive $\left(\mathrm{Prt}^{+}\right)$and proteinase-negative (Prt) strains grow at approximately the same rate (Citti et al, 1965; Thomas and Mills, 1981; Juillard and Richard, 1990, 1991). When the milk NPN is consumed, the Prt variants in pure culture stop growing, whereas the $\mathrm{Prt}^{+}$strains keep growing, owing to their proteinase activity (Thomas and Mills, 1981; Juillard and Richard, 1990).

As proteinases are cell-envelope located (Law and Kolstadt, 1983; Thomas and Pritchard, 1987; Laan et al, 1989), proteolysis products are expected to be released in the growing medium. Given that the Prt variants have the same peptide and amino-acid utilization systems as their parental strains (Exterkate, 1976; Van Boven and Konings, 1986; Krause et al, 1991), they are able to use these proteolysis products for growth, just as their parental strains do. This is supported by the observation that addition of peptides and amino acids isolated from a milk cultured by a $\mathrm{Prt}^{+}$strain of Lactococcus lactis subsp cremoris stimulated the growth of an isogenic Prt variant in milk (Otto, 1981). As a result, one can expect that when isogenic $\mathrm{Prt}^{+}$and $\mathrm{Pr}$ strains are cultured in association in milk, both types of cells competitively use the proteolysis products for growth. Therefore, the development of such a mixed culture should depend on the concentration of available NPN, which is in turn related to the percentage of $\mathrm{Prt}^{+}$cells in the mixture. Several authors (Garvie, 1959; Thomas and Lowrie, 1975; Winkel and Richardson, 1984) have shown that the maximum cell density of a mixed culture of $\mathrm{Prt}^{+}$and Prt strains depended on the initial percentage of $\mathrm{Prt}^{+}$celis, more precisely when the $\mathrm{Prt}^{+}$cells were $10-50 \%$ of the total population depending on the strains. Unfortunately, little quantitative information is available on the influence of the initial percentage of $\mathrm{Prt}^{+}$cells on the growth parameters of the $\mathrm{Prt}^{+}$and $\mathrm{Prt}$ bacteria and on the rate of milk acidification. It was the aim of this work to fill this gap using a particular couple of $\mathrm{Prt}^{+}$, $\mathrm{Prt}$ strains and simplified models to quantify the effect of their interaction on growth parameters and milk acidification rate. 


\section{MATERIALS AND METHODS}

\section{Strains}

A Prt strain of Lactococcus lactis subsp lactis (CNRZ 1076), and its Prt variant CNRZ 1075, were selected because when they were used in association for making soft cheeses, low bitterness was observed ( $L$ Vassal, personal communication). In addition, direct and indirect interactions in milk between these strains have been extensively studied (Juillard and Richard, 1989, 1990, 1991; Juillard, 1991).

The proteinase status of both isolates was confirmed on fast-slow-differential-agar (FSDA) (Huggins and Sandine, 1984), and using trinitrobenzene-sulfonic acid (TNBS) test (Chandan et al, 1982; Polychronadiou, 1988). On the basis of the hydrolysis of 60 different peptides (API ZYM Peptidase, Bio Mérieux, Marçy l'Etoile, France), both strains exhibited the same pattern, with similar intensities, suggesting that they were identical on the basis of peptidase activity.

The strains were stored at $-20^{\circ} \mathrm{C}$ in sterile litmus skimmed milk.

\section{Culture milk}

The culture milk was $10 \%$ (wt/vol) reconstituted low-heat non-fat dry milk NILAC [NIZO, Ede, the Netherlands] in sterile water. The bacterial quality of this milk was consistently good (less than $10^{2} \mathrm{cfu} / \mathrm{ml}$ ), and so no further heat treatment was needed. This to minimize the variability in the nutrient properties of milk usually caused by differences between heat treatments.

\section{Culture conditions}

The culture milk was inoculated with the $\mathrm{Prt}^{+}$ and $\mathrm{Prt}$ strains grown separately in autoclaved $\left(110^{\circ} \mathrm{C}\right.$ for $\left.10 \mathrm{~min}\right)$ reconstituted non-fat dry milk, with the aim of having the bacteria in an exponential growth phase (Juillard and Richard, 1989). Initial bacterial concentrations were fixed to $\mathrm{ca} 10^{7} \mathrm{cfu} / \mathrm{ml}$, with percentages of $\mathrm{Prt}^{+}$cells fixed for each experiment. Replicates were performed when necessary.
The cultures were incubated at $30^{\circ} \mathrm{C}$ without shaking or $\mathrm{pH}$ control. To minimize oxygen influence, the shape of flasks was such that the ratio of milk surface to volume never exceeded $0.1 \mathrm{~cm}^{-1}$, and samples were withdrawn from the bulk rather than the surface of the milk.

\section{Bacterial enumeration}

The chains of cells were first disrupted for $30 \mathrm{~s}$ using a mechanical blender (Ultra-Turrax model T25, Janke and Kunkel, Staufen, Germany) operating at $20000 \mathrm{rpm}$. It has been previously shown that the efficiency of this procedure was the same at all stages of growth, essentially yielding diplococci, and cell viability was not affected (Hassan et al, 1989). To get a differential enumeration of $\mathrm{Prt}^{+}$and $\mathrm{Prt}$ cells, appropriate dilutions were plated on FSDA using a spiral plater (Spiral System, model DS, Cincinnati, $\mathrm{OH}$, USA). The accuracy and precision of this plating method have been previously assessed (Hassan et al, 1989; Deschamps and Richard, 1990). In the present study the standard deviation of counts never exceeded $0.05 \log _{10} \mathrm{cfu} / \mathrm{ml}$.

\section{Curve analysis}

The $\log _{10}$ cfu/ml values were plotted against time and a linear regression analysis was performed on experimental points that seemed to fall into line. According to Hassan et al (1989), linearity was assumed when regression coefficients $\left(S_{y, x}\right)$ were under $0.07\left(\log _{10} \mathrm{cfu} / \mathrm{ml}\right)$, with no systematic deviations from the regression line.

The same analysis was performed on milk $\mathrm{pH}$ changes. The phase of rapid drop (usually between $\mathrm{pH}$ 6.2-4.8) was taken as linear if $S_{y, x}$ was under $0.02 \mathrm{pH}$ unit and the mean acidification rate $\mathrm{V}_{\mathrm{mar}}$ calculated by regression analysis (Demarigny et al, 1994).

\section{Determination of critical population levels}

The population level $\left(L_{1}\right)$ at which a shift between the first and the second growth phase oc- 
curred was calculated as the intersection of the 2 regression lines. The maximal population level $\left(L_{\max }\right)$ was the mean of 3 determinations on milk after $24 \mathrm{~h}$ of incubation.

\section{RESULTS}

\section{Growth parameters}

Figure 1 illustrates the effect of the $\mathrm{Prt}^{+1}$ Prt association on the growth of each kind of cells, with initially $12 \% \mathrm{Prt}^{+}$cells. The Prt variant is clearly stimulated in the

a

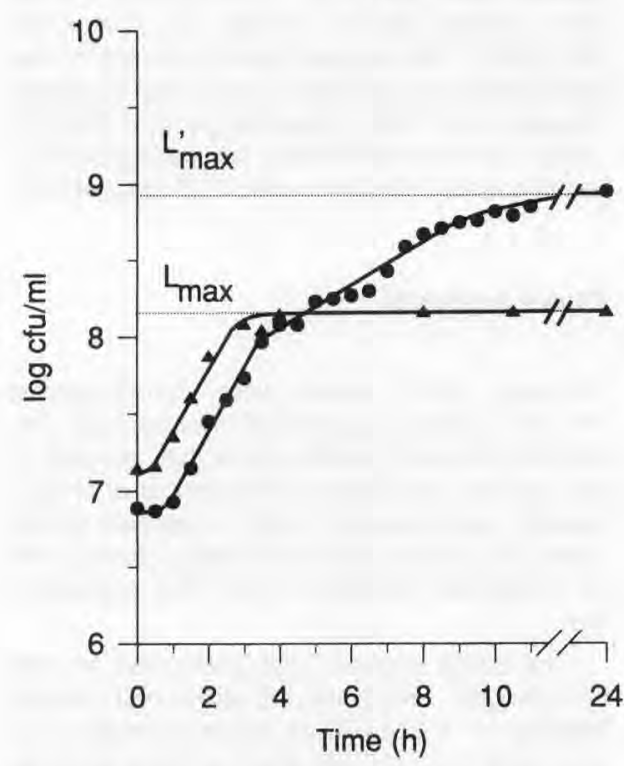

mixed culture (fig 1a); following an initial exponential growth phase up to $\mathrm{ca} 10^{8} \mathrm{cful}$ $\mathrm{ml}$, with a slope similar to that of the pure culture, a second growth phase takes place with a final Prt population in the mixed culture about five-fold higher than in pure culture. In this example, the experimental points oscillate around the regression line during the second exponential growth phase. However, in other experiments they fall into line better, as in previous work (Juillard and Richard, 1989).

On the other hand, the $\mathrm{Pt}^{+}$strain displayed 3 signs of outgrowth in mixed culture (fig $1 \mathrm{~b}$ ). The population level $L_{1}$ at the

b

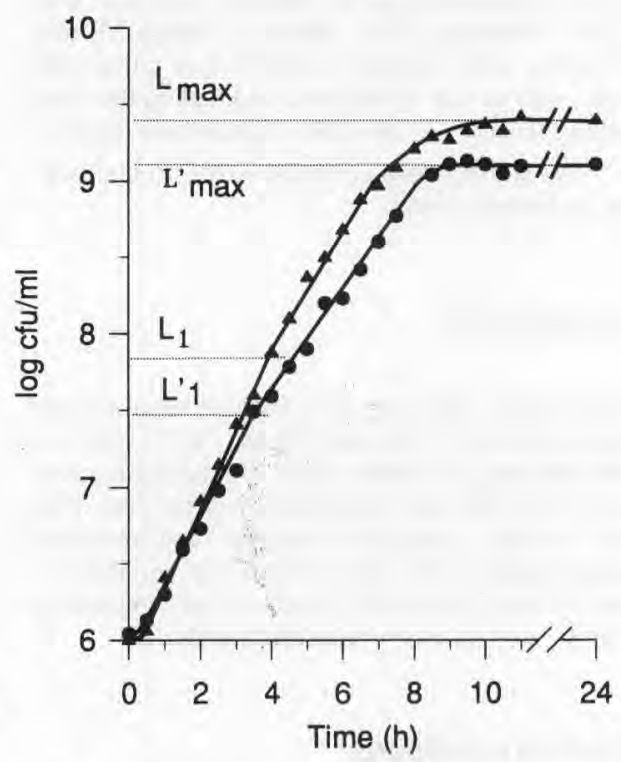

Fig 1. Growth of a) Lactococcus lactis subsp lactis CNRZ 1075 (proteinase-negative variant) and b) $L$

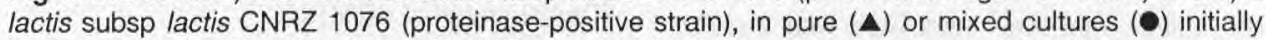
containing $12 \%$ of proteinase-positive (Prt) cells. $L_{\max }, L_{\max }^{\prime}$ : Maximal population levels (cfu/ml) of pure and mixed cultures, respectively. $L_{1}, L_{1}^{\prime}$ : Population of pure and mixed cultures, respectively, at the shift in growth phases.

Croissance de a) Lactococcus lactis subsp lactis CNRZ 1075 (variant protéase-négatif) et b) L lactis ssp lactis CNRS 1076 (souche protéase-positive), en culture pure (4) ou en culture mixte (-) contenant initialement $12 \%$ de cellules protéase-positives $\left(P r^{+}\right) . L_{\max }, L_{\text {max }}^{\prime}$ : niveau maximal de population $(\mathrm{ufc} / \mathrm{ml})$ des cultures pure et mixte respectivement. $L_{1}, L_{1}^{\prime}$ : Population des cultures pures et mixtes, respectivement, au changement de phase de croissance exponentielle. 
change in growth rate, calculated as the intersection of the regression lines, decreased markedly (about 0.4 log units), the growth rate in the second exponential phase was significantly reduced and the maximal $\mathrm{Prt}^{+}$population in the mixed culture was approximately half of the pure culture.

As the same pattern was observed with different $\mathrm{Prt}+\mathrm{Prt}$ ratios, 4 parameters were selected to describe the growth of each strain and for a tentative quantitation of their interaction: $S_{1}$ and $S_{2}\left(\log _{10} \mathrm{cfu} / \mathrm{ml}\right.$ per $h$ ), the slopes of the two consecutive exponential growth phases, and $L_{1}$ and $L_{\text {max }}$, $\left(\log _{10} \mathrm{cfu} / \mathrm{ml}\right)$, the populations at the shift in growth phases and at the end of growth, respectively.

The reproducibility of these parameters was assessed using 6 replicate experiments. As shown in table I, the range of variations for slopes was under $0.06 \log _{10}$ $\mathrm{cfu} / \mathrm{ml}$ per $\mathrm{h}$, and under $0.3 \log _{10} \mathrm{cfu} / \mathrm{ml}$ for population levels.

Table I. Reproducibility of parameters describing the growth in skim milk of Lactococcus lactis subsp lactis CNRZ 1076 (Prt+ strain) and CNRZ 1075 (Prt strain) at $30^{\circ} \mathrm{C}$ and resulting acidification*.

Reproductibilité des paramètres décrivant la croissance à $30^{\circ} \mathrm{C}$ dans du lait de Lactococcus lactis subsp lactis CNRZ 1076 (souche Prt') et CNRZ 1075 (variant Prt) et l'acidification qui en résulte *.

$S_{1}$ : Growth rate during the first phase $\left(\log _{10} \mathrm{cfu} / \mathrm{ml}\right.$ per $\left.\mathrm{h}\right)$
Average
$0.51 \pm 0.02$
$0.49 \pm 0.02$
Extreme values
$0.48 ; 0.53$
$0.47 ; 0.53$

$S_{2}$ : Growth rate during the 2 nd phase $\left(\log _{10} \mathrm{cfu} / \mathrm{ml}\right.$ per $\left.\mathrm{h}\right)$

$\begin{array}{lll}\text { Average } & 0.36 \pm 0.02 & \text { no } \\ \text { Extreme values } & 0.33 ; 0.38 & \text { no }\end{array}$

$L_{1}$ : Population at growth phase shift $\left(\log _{10} \mathrm{cfu} / \mathrm{ml}\right)$
Average
$7.9 \pm 0.1$
Extreme values
$7.8 ; 8.1$

$L_{\text {max }}:$ Total population in stationary phase $\left(\log _{10} \mathrm{cfu} / \mathrm{ml}\right)$
Average
$9.3 \pm 0.1$
$8.2 \pm 0.1$
Extreme values
$9.3 ; 9.4$
$8.1 ; 8.3$

$S_{\mathrm{a}}$ : Acidification rate during the rapid $\mathrm{pH}$ drop phase $(\mathrm{pH}$ unit/ $\mathrm{h})$
Average
$-0.56 \pm 0.04$
Extreme values
$-0.51 ;-0.60$
nd
nd
$\mathrm{t}_{4.8}$ : Time to reach $\mathrm{pH} 4.8$ (h)
Average
Extreme values
$7.25 \pm 0.25$
$7 ; 7.5$

nd

nd

\footnotetext{
- Average of 6 repetitions with confidence intervals at $P=0.95$; no: not observed; nd: not determined.

- Moyenne de 6 répétitions avec intervalle de confiance à $\mathrm{P}=0,95 ;$ no: non observé; nd: non déterminé.
} 


\section{Acidification parameters}

An example of the effect of mixing $\mathrm{Prt}^{+}$ and Prt strains on milk acidification rate is shown in figure 2 . The overall pattern of $\mathrm{pH}$ decrease is similar to that of the pure culture of the $\mathrm{Prt}^{+}$strain, with an apparently linear rapid drop $\left(S_{y, x}<0.02 \mathrm{pH}\right.$ unit) between $\mathrm{pH} 6.2-4.8$. However, the acidification rate is lower for the mixed culture than for the pure culture of the $\mathrm{Prt}^{+}$strain, although the initial total populations were the same.

To quantify the effect of the initial percentage of the $\mathrm{Prt}^{+}$strain on milk acidification, 2 parameters were selected: $V_{\text {mar }}$, the slope of $\mathrm{pH}$ decrease between $\mathrm{pH} 6.2-$ 4.8 and $\mathrm{t}_{4.8}$, the time to reach $\mathrm{pH} 4.8$, at which milk usually coagulates at $30^{\circ} \mathrm{C}$. $V_{\text {mar }}$ was calculated by regression analysis. The reproducibility of these 2 parame-

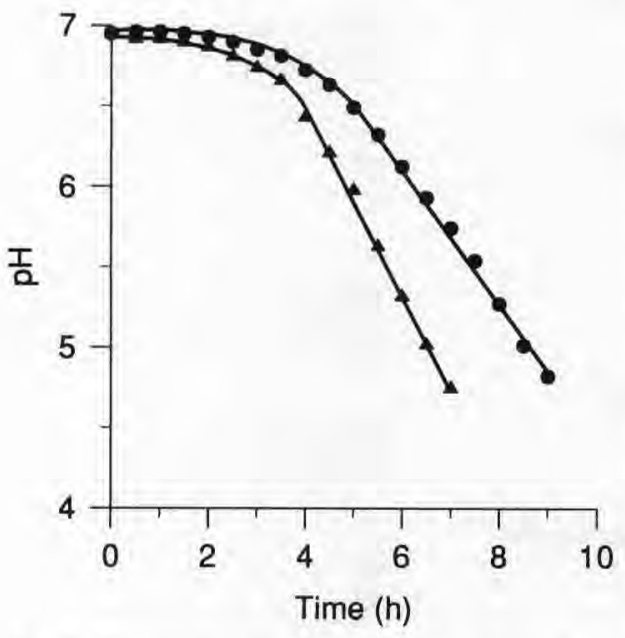

Fig 2. Change in milk $\mathrm{pH}$ during the pure culture of the $\mathrm{Prt}^{+}$strain $(\mathbf{\Delta})$ and the mixed culture of the $\mathrm{Prt}^{+}$and $\mathrm{Prt}$ strains $(\bullet)$. Conditions are the same as for the mixed culture illustrated in figure 1.

Évolution du $\mathrm{pH}$ du lait durant la croissance de la souche $P r^{+}(\mathbf{\Delta})$ et au cours de la culture mixte des souches Prt+ et Prt (•). Les conditions de la culture mixte sont celles de la figure 1. ters was determined using only pure cultures of the $\mathrm{Prt}^{+}$strain (table I). The parameters for the Prt strain were too low to be determined with precision.

\section{Influence of inoculum composition on the growth parameters of each strain}

Both Prt+ and Prt strains displayed a biphasic growth in association, regardless of the initial inoculum composition. Moreover, all standard deviation of the regression $S_{y, x}$ were systematically under $0.07 \mathrm{log} \mathrm{cfu} / \mathrm{ml}$, ensuring fairly good linearity of the 2 growth phases (Hassan et al, 1989).

The initial percentage of $\mathrm{Prt}^{+}$cells had no significant effect on $S_{1}$, the growth rate during the first exponential growth phase of both type of cells $(P<0.05)$. In addition, the shift from the first to the second exponential growth phase occurred simultaneously for both strains, with a combined population ( $\mathrm{Prt}^{+}$and $\mathrm{Prt}$ cells) of $\mathrm{ca} 10^{8}$ $\mathrm{cfu} / \mathrm{ml}$. It is worth noting that this total population coincides with that at the end of the first growth phase of a pure culture of both strains. As they grew at the same rate up to this point, the percentage of $\mathrm{Prt}^{+}$cells remained constant.

The effect of the initial percentage of $\mathrm{Prt}^{+}$cells had on $S_{2}$, the second exponential growth rate of each type of cells, is illustrated in figure 3 . The higher this percentage, the higher the value of $S_{2}$ for both strains, with a dramatic drop for inocula containing less than $20 \% \mathrm{Prt}^{+}$cells.

As shown in figure $4 a$, a small change in composition of inocula containing less than $20 \%$ of $\mathrm{Prt}^{+}$cells had a tremendous effect on the total flora $\left(L_{\text {max }}\right)$ at the end of the culture. For example, an increase of only ca $0.1 \%$ of $\mathrm{Prt}^{+}$cells in this interval caused a doubling of the final combined population. In contrast, a modification in 
composition of inocula containing more than $20 \%$ of $\mathrm{Prt}^{+}$cells did not significantly affect the final total flora. However, the percentage of $\mathrm{Prt}^{+}$cells at the end of the culture markedly changed (fig $4 b$ ). This was a consequence of a higher growth rate for the $\mathrm{Prt}^{+}$strain during the second exponential growth phase than for the Prt variant, as shown in figure 3 .

\section{Influence of initial inoculum composition on milk acidification parameters}

Milk acidification strongly depended on inoculum composition, especially when it contained less than $20 \%$ of $\mathrm{Prt}^{+}$cells (fig 5). The lower this percentage, the lower $\mathrm{V}_{\text {mar }}$, the mean acidification rate during the rapid drop in milk $\mathrm{pH}$. As for the growth parameters, a small change in inoculum composition under the critical limit of $20 \%$ of $\mathrm{Prt}^{+}$cells strongly affected the acidification parameters. For example, increasing the initial percentage of $\mathrm{Prt}^{+}$bacteria by only $1 \%$ induced an increase of ca $50 \%$ in $\mathrm{V}_{\mathrm{mar}}$. As a consequence of the effect of the

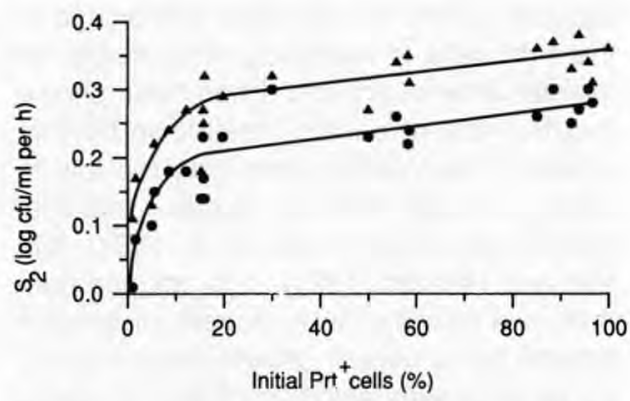

Fig 3. Influence of the initial percentage of $\mathrm{Prt}^{+}$ cells on the slope of the second exponential growth phase $\left(S_{2}\right)$ of the $\mathrm{Prt}(\bullet)$ and $\mathrm{Prt}^{+}(\mathbf{\Delta})$ strains cultured in association.

Influence du pourcentage initial de cellules Prt+ sur la pente de la seconde phase de croissance $\left(\mathrm{S}_{2}\right)$ des souches Prt $(\bullet)$ et $\mathrm{Prt}^{+}(\boldsymbol{\Delta})$ cultivées en association. initial percentage of $\mathrm{Prt}^{+}$bacteria on $\mathrm{V}_{\text {mar }}$, $t_{4.8}$, the time for milk clotting was prolonged. For example, $t_{4.8}$ was $18 \mathrm{~h}$ with a mixture initially containing $2.5 \%$ of $\mathrm{Prt}^{+}$ cells compared to $7.5 \mathrm{~h}$ for a pure culture of the parental strain.

With inocula containing more than $20 \%$ of $\mathrm{Prt}^{+}$cells, both acidification parameters $V_{\text {mar }}$ and $t_{4.8}$, increased slowly up to the maximal values of the pure culture of the $\mathrm{Prt}^{+}$strain. As an illustration, with a mixture initially containing $25 \%$ of $\mathrm{Prt}^{+}$strains,
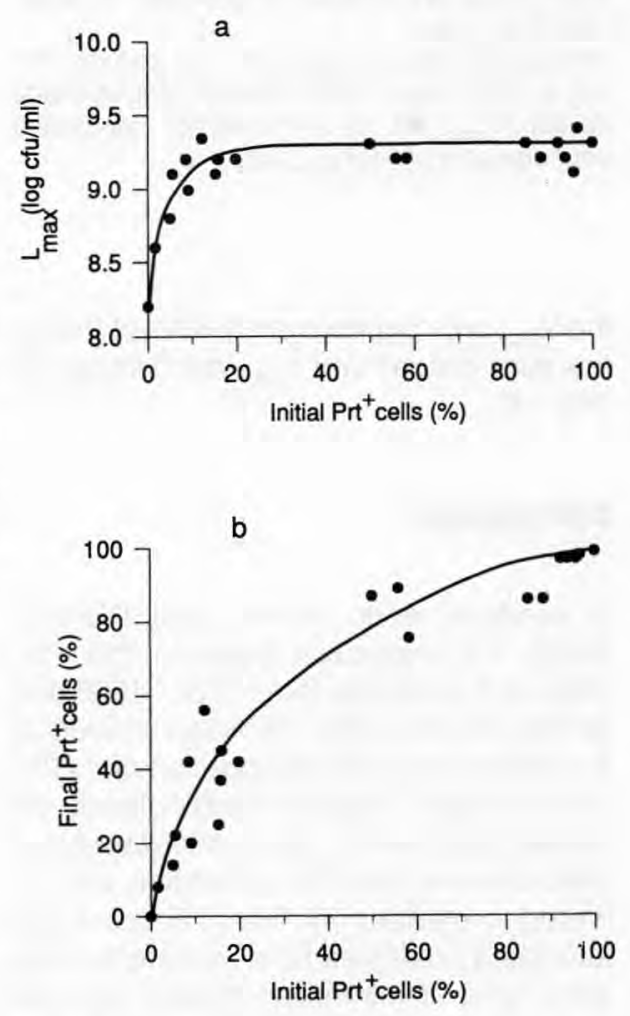

Fig 4. Influence of the initial percentage of $\mathrm{Prt}^{+}$ cells on a) the maximal level $\left(L_{\text {max }}\right)$ reached by the total flora of the mixed culture, and b) its final composition.

Influence du pourcentage initial de cellules Prt+ sur a) le niveau maximum $\left(L_{\text {max }}\right.$ ) atteint par la flore totale de la culture mixte, et b) sur sa composition finale. 


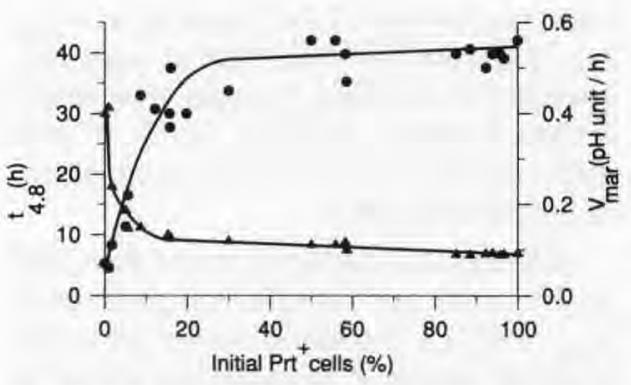

Fig 5. Influence of the initial percentage of $\mathrm{Prt}^{+}$ cells on the slope of the linear phase of acidification $\left(\mathrm{V}_{\text {mar }} ; \bullet\right)$, and the time needed to reach $\mathrm{pH} 4.8\left(t_{4.8} ; \mathbf{\Delta}\right)$.

Influence du pourcentage initial de cellules Prt+ sur la pente de la phase linéaire d'acidification du lait $\left(V_{\text {mar }} \bullet\right)$, et sur le temps nécessaire pour atteindre $\mathrm{pH} 4,8\left(\mathrm{t}_{4,8} ; \mathbf{\Delta}\right)$.

the $\mathrm{V}_{\text {mar }}$ was approximately $80 \%$ of that of the pure culture and $t_{4.8}$ was delayed by only $1 \mathrm{~h}$.

\section{DISCUSSION}

In previous work (Juillard and Richard, 1989), the interaction between the $\mathrm{Prt}^{+}$ strain of $L$ lactis ssp lactis CNRZ 1076 and its Prt variant CNRZ 1075 was studied at a constant inoculum composition of ca $9 \%$ of $\mathrm{Prt}^{+}$strains. Under these conditions, we showed that the Prt population was stimulated whereas the $\mathrm{Prt}^{+}$population was inhibited, compared with that of the pure culture. Data presented here indicate that the same kind of interaction occurs between these strains, regardless of the initial percentage of $\mathrm{Prt}^{+}$strains in the inoculum. Moreover, the extent of the interaction is closely related to the initial proportion of the $\mathrm{Prt}^{+}$strains in the mixture. The higher this percentage, the stronger the stimulation of the growth of the Prt population. On the other hand, the lower this initial
$\mathrm{Prt}^{+}$percentage, the greater the growth inhibition of the $\mathrm{Prt}^{+}$population.

Furthermore, previous studies of these specific organisms in sequential cultures (Juillard and Richard, 1990, 1991) have established that the NPN initially present in the milk accounted for the first exponential growth phase of both strains, whereas the second exponential growth phase of the $\mathrm{Prt}^{+}$strain relied on the utilization of proteolysis products. Thus, the interactive growth of the isogenic Prt+ and Prt strains can be explained as follows. During the first exponential growth phase, the 2 types of cells grow at the same rate, regardless of the initial percentage of $\mathrm{Prt}^{+}$cells. This rate is similar to that of pure cultures of these organisms, indicating the equivalence of both types of cells in their competition for NPN. Therefore, the end of this first exponential growth phase occurs simultaneously for both strains and when the total population (ie $\mathrm{Prt}^{+}+\mathrm{Prt}$ counts) is equal to that of the pure cultures of these organisms. A competition in favour of 1 of the strains occur as soon as the NPN content of the milk becomes too low to sustain the initial exponential rate of growth of both strains, and only the breakdown of the caseins by the cell-envelope proteinase of the $\mathrm{Prt}^{+}$cells is ultimately responsible for maintenance of growth. It has been shown that the rate of casein breakdown by $\mathrm{Prt}^{+}$ strains of lactococci alone was too low to supply enough NPN to sustain maximal growth rate (Hugenholtz et al, 1987; Juillard and Richard, 1991). It is obvious then that, in a mixed culture, a weak proteolytic activity limits overall growth, primarily because of growth inhibition of the $\mathrm{Prt}^{+}$strain due to competition for proteolysis products with the Prt strain.

The consequences of this competition are of great technological importance, as already outlined by several authors (Garvie, 1959; Thomas and Lowrie, 1975; Winkel and Richardson, 1984). The present 
study shows that the milk acidification rate is dramatically affected at initial concentrations of the $\mathrm{Prt}^{+}$strain below $20 \%$.

So far, the growth of all $\mathrm{Prt}^{+}$strains of lactococci in skimmed milk studied in our laboratory was biphasic (unpublished results), as already observed for some (Turner and Thomas, 1975; Thomas and Turner, 1977). If a low rate of proteolysis is the general cause of this growth pattern, then a competition should occur between any isogenic pair of $\mathrm{Prt}^{+}$. Prt lactococci when associatively grown in milk. It should also be both scientifically and technologically interesting to investigate the effect on growth and acidification parameters of interactions between non-isogenic strains of lactococci.

\section{REFERENCES}

Chandan RC, Argyle PJ, Mathison GE (1982) Action of Lactobacillus bulgaricus proteinase preparations on milk proteins. J Dairy Sci 65, 1408-1413

Citti JE, Sandine WE, Elliker PE (1965) Comparison of slow and fast acid-producing Streptococcus lactis. J Dairy Sci 48, 14-18

Demarigny $Y$, Juillard V, Deschamps N, Richard $\mathrm{J}$ (1993) Comparaison sur le plan pratique de trois modèles d'étude de la cinétique d'abaissement du $\mathrm{pH}$ du lait cultivé par une souche de Lactococcus lactis. Proposition du concept "Vmar". Lait 74, 23-32

Deschamps N, Richard J (1990) Méthode rapide de vérification du calibrage de l'ensemenceur spiral. Lait 70, 127-132

Exterkate FA (1976) The proteolytic system of a slow lactic acid producing variant of Streptococcus cremoris HP. Neth Milk Dairy J 30, 3-8

Garvie EI (1959) Some observations on slow and fast acid-producing variants of strains of Streptococcus cremoris and Str lactis used as cheese starters. J Dairy Res 26, 227-237

Hassan Al, Deschamps N, Richard J (1989) Précision des mesures de vitesses de croissance des streptocoques lactiques dans le lait basées sur la méthode de dénombrement microbien par formation de colonies. Étude de référence avec Lactococcus lactis. Lait $69,433-447$

Hugenholtz J, Dijkstra M, Veldkamp $H$ (1987) Amino-acid limited growth of starter cultures in milk. FEMS Microbiol Ecol 45, 191-198

Huggins AM, Sandine WE (1984) Differentiation of fast and slow milk-coagulating isolates in strains of lactic streptococci. J Dairy Sci 67 , 1674-1679

Juillard V (1991) Interactions directes et indirectes entre souches protéolytiques et variants isogéniques non protéolytiques de Lactococcus lactis au cours de leur croissance dans le lait. Thèse doctorat, Univ Paris VII, Paris

Juillard $V_{r}$ Richard J (1989) Etude de l'interaction entre souches protéolytiques de streptocoques lactiques mésophiles et leurs variants non protéolytiques, au cours de leur croissance dans le lait. Lait 69, 291-304

Juillard V, Richard J (1990) Indirect interaction in milk between proteolytic and isogenic nonproteolytic strains of Lactococcus lactis. I. Effect of pre-culturing by a non-proteolytic variant. Lait 70, 425-438

Juillard V, Richard J (1991) Indirect interaction in milk between proteolytic and isogenic nonproteolytic strains of Lactococcus lactis. II. Effect of pre-culturing by a proteolytic strain. Lait 71, 55-64

Krause DA, Broome MC, Hickey MW (1991) The isolation and characterization of a proteinase negative cheese starter. Aust J Dairy Technol 46, 1-5

Laan H, Smid EJ, Tan PST, Konings WN (1989) Enzymes involved in degradation and utilization of casein in Lactococcus lactis. Neth Milk Dairy J 43, 327-345

Law BA, Kolstadt J (1983) Proteolytic systems in lactic acid bacteria. Antonie Van Leeuwenhoek 49, 225-245

Otto R (1981) An ecophysiological study of starter streptococci. Ph D Thesis, Groningen Univ, Haren, the Netherlands

Polychronadiou A (1988) A simple procedure using trinitrobenzenesulfonic acid for monitoring proteolysis in cheese. J Dairy Res 55 , 585-596

Thomas TD, Lowrie RJ (1975) Starters and bacteriophages in lactic acid manufactures. I. Mixed strain starters. J Milk Food Technol $38,269-274$ 
Thomas TD, Turner KW (1977) Preparation of skim milk to allow harvesting of starter cells from milk cultures. NZJ Dairy Sci Technol 12, 15-21

Thomas TD, Mills OE (1981) Proteolytic enzymes of starter bacteria. Neth Milk Dairy $J$ 35, 255-273

Thomas TD, Pritchard GG (1987) Proteolytic enzymes of dairy starter cultures. FEMS Microbiol Rev 46, 245-268
Turner KW, Thomas TD (1975) Uncoupling of growth and acid production in lactic streptococci. NZJ Dairy Sci Technol 10, 162-167

van Boven A, Konings WN (1986) The uptake of peptides by micro-organisms. Neth Milk Dairy J 40, 117-127

Winkel SA, Richardson GH (1984) Cell mass and acid production of proteinase-positive and proteinase-negative lactic cultures in buffered nonfat milk. J Dairy Sci 67, 2856-2859 